\title{
Formation of changing coalitions in EU agricultural policy - conceptualization assumptions for political science research
}

\section{Introduction}

The Common Agricultural Policy is one of the oldest and most regulated sector policies in the Community law whose aim is to bring together EU Member States. As a significant share of the EU budget is spent on agriculture and rural development (38\% of budget), both a reform of the CAP, as well as its future financing, fall within the interest of all Member States, European and national agricultural organisations and trade unions. On the other hand, the quest for a coherent vision of the EU agricultural policy is hindered by the collateral (national) interests of each individual member state and by the existence of a multitude of agriculture types based on the traditional, commercial or environmentally sensitive model (Kowalski, Wigier, Bułkowska, 2013, p. 9). Experts point out that EU Member States have radically diverse expectations of the future shape of the CAP (Majewski, Malak-Rawlikowska, 2018, pp. 21-22).

The current debate on the CAP reform post-2020 is taking place in times of particular difficulty for the EU, when the united Europe, weakened from the Eurozone crisis, is struggling with the UK leaving the community structures (budgetary constraints will be, among other things, the consequences of Brexit), the growing influence of Eurosceptic parties and disintegration tendencies, the massive influx of immigrants, the ever-growing terrorist threat, and adverse climate and demographic change in European rural areas (Majewski, Malak-Rawlikowska, 2018, p. 10). Just as in the case of the last reform of 2013, the European Commission argues that changes in the CAP are a necessary response to the challenges facing agriculture and rural areas, such as food security, globalisation, changing prices, rising costs of production, the weakening position of farmers in the distribution chain, resource efficiency, deteriorating soil and water quality, and depopulation of rural areas. The European Commission calls for the new CAP to be adapted to the needs and determinants of individual Member States.

\section{Assessment of sources and state of research}

Numerous publications of, inter alia, the Institute of Agricultural and Food Economics of the National Research Institute, the Warsaw University of Life Sciences, the Institute of Rural and Agricultural Development of the Polish Academy of Sciences, as well as the Foundation of Assistance Programmes for Agriculture (FAPA), or, until 2009, of the Department for Integration Policy at the Office of the Committee for the 
European Integration ${ }^{1}$, have attempted to provide an outline for the debate on the future of the CAP, which has raged since the end of the 20th century. The analyses show the development of the EU agricultural policy throughout the years from the perspective of the interests of Poland and other selected Member States. From among numerous authors dealing with the evaluation of changes occurring in the CAP and the issues of implementation and cooperation of states in the implementation of the EU agricultural policy, noteworthy works include those authored among others by Agnieszka BaerNawrocka, Andrzej Czyżewski, Mirosław Drygas, Renata Grochowska, Katarzyna Kosior, Iwona Nurzyńska, Walenty Poczta, Zdzisław W. Puślecki, Sebastian Stępień, Dorota Stankiewicz, Jerzy Wilkin, Maciej Walkowski, Katarzyna Zawalińska. The focal point of scientific research is, in many cases, the analysis of Polish priorities in the context of the CAP reforms and the assessment of changes in budget financing of agriculture and rural areas proposed by the government of the Republic of Poland. Significantly fewer articles assessed the new solutions adopted in the CAP by the selected Member States or analysed the national governments' positions on the directions for further development of the EU farming sector (Bryła, 2008; Nawrot, 2008; Gadyński, Hadyńska, 2008; Popławski, 2011; Chmielewska, 2008; Dybowski, 2008; Szuba, Mrówczyńska-Kamińska, 2014; Kowalski, Wigier, Bulkowska, 2013).

Apart from the exogenous determinants of the CAP reforms (such as international agreements within the WTO, environmental protection or climate change) which provide the political, social, economic, and institutional foundation for the changes, the analysed endogenous factors include: the Member States' interests, budgetary constraints and the influence of the European and national agricultural organisations. The process of developing the Multiannual Financial Framework, and in that context the process of the CAP negotiations, is the subject of many articles and papers published by Polish political scientists and economists (Paluszak, Sapała, 2013; Tomaszyk, 2013; Bielka, 2013; Grochowska, Kiryluk-Dryjsk, 2016; Grochowska, Kosior, 2016).

\section{Selection of research problems}

It must be underlined that implementation of the CAP is the result of a hard-won compromise that is the culmination of a long discussion on the future budget and a derivative of the bargaining power of the coalitions formed by Member States (Drygas, Nurzyńska, 2018, pp. 58-59). The institutions which by virtue of the Treaty on the Functioning of the Union and the Treaty on the EU in the Lisbon Treaty version decide in the ordinary legislative procedure on the shape of the CAP are the EU Council and the European Parliament. When analysing coalitions formed by Member States around the EU agricultural policy, the focus of the considerations should fall on the multilayered Council (working groups, the Agriculture and Fisheries Council, as well as the

${ }^{1}$ A 2008 three-volume publication of the Office of the Committee for the European Integration, Department for Integration Policy, comprising the following parts: 1) Reform of the Common Agricultural Policy of 2008 (health check) from the perspective of interests of selected Member States, 2) The Reform of the Common Agricultural Policy in the context of the needs and interest of the Polish farming sector, 3) Agricultural Policy of the European Union CAP in 2013. 
Special Agricultural Committee) which is the "arena" for negotiations among Member States and the key player in the inter-institutional CAP arrangements (Lawniczak, 2014; Ławniczak, 2017; Kleinowski, 2014).

Regular political debates on the financial framework (2000-2006, 2007-2013 and 2014-2020) have revealed a long-standing rift between Member States which runs along the question of whether the CAP should aim to ensure equality among the Member States or to enhance economic efficiency. On one hand, net contributors visibly endeavour to introduce limitations at the level of CAP funds allocation (Germany, the Netherlands, the United Kingdom, Belgium, Luxembourg, Denmark and Sweden), while on the other the net CAP recipients (among others France, Spain, Greece, Portugal, Italy and the new Member States) object and argue that renationalisation of the farming sector goes against the principle of European solidarity. The advocates of austerity not only support a reduction in the share of agricultural expenditure in the European Union budget ${ }^{2}$ but are also in favour of passing on the costs to national budgets (Purgat, 2011, p. 28). Member States increasing the agricultural policy financing share and needs would mean passing even broader scope of competence from the Community on to the national level. Another divide between the Member States concerns possible further liberalisation of the CAP. In favour of the pro-market orientation of the CAP are, among others, Denmark, Sweden, the United Kingdom, while France, Portugal and Spain are among those against it. Renationalisation is favoured by the United Kingdom, the Netherlands and Sweden, while Austria, Denmark, Portugal and Spain are decidedly against such process (Majewski, Malak-Rawlikowska, 2018, pp. 21-22).

Researching how coalitions of Member States in the EU agricultural policy are formed is a valid and topical issue in view of the work on the shape of the CAP which started at the beginning of 2017 as well as of the ongoing discussion on the new financial framework for 2021-2027. The aim of the analysis would be to present the varied interests of the individual Member States with respect to the planned CAP reform. It seems worthwhile to study the position of the old Member States which previously had a considerable influence on the CAP debate within the Council (France, Germany, Italy, Spain) and also of those new Member States which are currently engaged in such a debate (Poland, Hungary, Bulgaria, Romania). The considerations should concentrate on how the views of Member States are presented in the public debate on the directions for the Common Agricultural Policy in relation to the European Commission's communications and specific legislative proposals.

A detailed study of the CAP priorities of individual Member States, and thus of their readiness to make coalitions with other debate participants, should be preceded by an assessment of the position of agriculture and rural areas in a given state. The role of the agriculture sector in particular EU Member States is quite diverse and depends on the agrarian structure, agricultural productivity, agricultural sector employment and the share of agriculture in the national GDP (Baer-Nawrocka, Markiewicz, 2010, pp. 9-15). The existing divisions result from the fact that the EU

${ }^{2}$ While in the 1970 s over $80 \%$ of the EU budget was spent on the CAP, between 2014-2020 agricultural sector spending and rural development expenditure accounted for only $37.8 \%$ of the budget. 
tolerates the functioning of many varieties of the national agricultural policy, which in turn are a consequence of historical differences in the agriculture and the structure of individual countries and regions. Some Member States are more, while others are less, inclined to support their domestic farmers, which results from their differing visions of agriculture. Some states support a liberal approach (competitive agriculture paradigm and global agriculture paradigm), others want a close alignment of the agricultural sector with the environmental, climate and cohesion policies (multifunctional agriculture paradigm), or maintaining protectionism (dependence/state aid paradigm) (Zawojska, 2006, pp. 64-65; Kosior, 2014, pp. 41-45). It must also be emphasised that the agricultural sector is segmented not only among individual states but also within the states with a larger surface area and this is a consequence of the diverse natural determinants and the advancement of structural transformation affecting the agricultural sector in the old Member States since the mid-1970s (Babiak, 2010, p. 87-97).

An additional element which differentiates Member States in terms of the CAP implementation is a different method for calculating direct payments under the Single Payment Scheme, ${ }^{3}$ which has been in operation since the Luxembourg reform of 2003, wherein the payments are calculated according to 1) the reference historical model or 2) the regional model or 3) the hybrid model, or according to the Single Area Payment Scheme in the new Member States. Despite the changes made under Regulation (EC) No 1307/20132 effective since 1 January 2015, which has introduced the Basic Payment Scheme, the simplified Single Area Payment Scheme has been maintained for the new Member States.

The old Member States have a much higher level of income per one agricultural holding in terms of its ratio to the outlays involved or the production volume, which is strictly linked to higher direct payments for the EU-15 farmers. In the new Member States, capital outlays per 1 ha of agricultural areas are less than half of those in EU-15, which causes low land productivity and, as a consequence, contributes to the smaller competitiveness of this sector on the single agricultural market. Despite the actions taken to align the level of direct payments for the old and new EU farmers, until 2020 the differences in payments per hectare as high as 4:1 in favour of the EU$15^{4}$ will apply. This disparity gives rise to the demands from the new Member States for a fairer distribution of the CAP funds among EU Member States (Miecznikowska, 2016, pp. 173-195).

Another determining factor for a Member State's position on the CAP is the national ceilings fixing the amount of direct support granted to farmers and the amount of EU funds allocated for the rural development in the individual Member States (Wilkin, 2008). The states are divided over the placing of particular support instru-

3 The single area payment is calculated according to the historical model in Austria, Belgium, France, Greece, Ireland, Italy, the Netherlands, Portugal, Scotland, Spain, Wales. The mixed model (the so-called hybrid model) is used to calculate direct payments in: Denmark, Luxembourg, Northern Ireland, Sweden, Finland, Germany, England, while the regional model is only used in Malta and Slovenia (for more see: Prus, Mickiewicz, 2014, pp. 111-125).

${ }^{4}$ In 2015 the amount of direct payments per ha in the Netherlands was EUR 418, whereas in Latvia only EUR 109 and in Poland EUR 209 (see: Biernat-Jarka, 2016, p. 3). 
ments in the appropriate CAP pillar, as both the criterion of allocation of funds among the Member States and the size of appropriations for a specific objective are differential. ${ }^{5}$

The present discussion taking place at the forum of the Agriculture and Fisheries Council and the European Parliament on the future of the Common Agricultural Policy began already in February of 2017 when the European Commission announced a communication on the modernisation and simplification of the CAP (Strategic, 2016) in which it carried out a preliminary evaluation of the influence of various future policy options in the environmental, social, and economic dimensions, as well as in terms of simplifications reducing the administrative burdens. At the same time, the European Commission initiated a three-month public consultation (February-May 2017) on the modernisation and simplification of the Common Agricultural Policy of the European Union post-2020. ${ }^{6}$ Next, based on 320 thousand submitted questionnaires, the European Commission first prepared a full report (Modernising and Simplifying, 2017) and a few months later, in November 2017, published a communication entitled "The Future of Food and Farming." The latter document contains proposed directional changes to the Common Agricultural Policy to be implemented post-2020, including the reduction of differences in the support level among Member States, the continuation of environmental actions and combating climate change. The European Commission proposes to give Member States more freedom as to how to use their allocations, which means handing over a part of the authority, including the power to decide autonomously on transfers of appropriations from the EU budget. Such transfer of competence would allow Member States to respond to the problems of farmers and rural communities more efficiently by matching their actions to the specific national and regional conditions. In 2018 the European Commission presented a CAP reform package containing three draft regulations: 1) a central regulation on the CAP strategic plans comprising the direct payments, sector interventions and rural development; 2) a so-called horizontal regulation concerning the CAP financing, management and monitoring; 3) a regulation amending and updating, among other things, the regulation on the common organisation of agricultural markets and the regulation on the scheme for agricultural products and foodstuffs.

Simultaneously with the reform of the CAP, the EU has been debating and working on the Multiannual Financial Framework post-2020 which determines, among other things, the issues of EU agricultural policy financing. The subsequent meetings of the Agriculture and Fisheries Council of the European Union and the bilateral or multilateral meetings at the government level devoted to the future and reform of the Common Agricultural Policy provide an opportunity to seek out like-minded coalition partners in

${ }^{5}$ The EU 2014-2020 budget provides for the total of EUR 408,313 billion for commitments. $75.6 \%$ of those funds will be allocated to the first pillar, while allocations to the actions related to rural development - that is the second pillar - will amount to $24.4 \%$.

${ }^{6}$ The Internet public consultation on the modernisation and simplification of the CAP began on 2 February 2017 and lasted until 2 May 2017. They were open to any interested citizens and organisations willing to complete a questionnaire available in 23 official languages of the EU. The questionnaire contained 28 closed-ended questions (with more than one possible answer) and five open-ended questions with an option to attach position papers. 
terms of the future of the CAP. ${ }^{7}$ During 2017 and 2018 Member States developed their positions on the shape of the future CAP, setting their priorities and commenting on the changes proposed by the Commission. On 1 June 2018, the European Commission presented its legislative proposals on the changes to the implementation of the CAP post2020, including a communication entitled "A Modern Budget for a Union that Protects, Empowers and Defends The Multiannual Financial Framework for 2021-2027".

\section{Hypotheses and research questions}

A hypothesis whose verification would be material for the study of coalition formation mechanisms is one that the foundation for the shaping of the CAP is a clash of the states' national interests (Łoś-Nowak, 1997). Moreover, the financial situation of holdings in the individual EU Member States in terms of their production and economic outturn has a considerable impact on the position of a given national government on the future of the CAP and the scope of its financing from the EU budget. Therefore, due to the varying size and structure of the agricultural sector, as well as the effectiveness of CAP funds absorption, the disparities also among the new Member States increase. Poland, Hungary, Bulgaria and Romania demand more financial solidarity, including fair distribution of funds, while Slovakia and the Czech Republic are more willing to seek savings in this sector in favour of larger investments into other EU policies. Thus, in terms of the future of the CAP post-2020, it will be difficult to achieve unanimity within the Visegrad Group (V4).

A partial hypothesis would assume the existence of a clear divide between the new and old Member States in the negotiations on the future of the CAP and during the MFF talks (2014-2020, 2021-2027). The line of conflict would run between the CAP net recipients advocating to maintain the current shape of the agricultural policy and the net contributors postulating a partial or total renationalisation of the CAP expenditure and promoting solutions involving serious budget cuts or reallocation of funds in the EU budget (Rembisz, Kulak, 2010, pp. 12-45).

At the same time, an accommodating approach of some net contributors towards the maintenance of the reformed CAP, despite its high cost, results from the evolution of the policy and the shift towards multifunctional agriculture which, apart from agricultural production, also focuses on environmental, social and cultural functions. Moreover, as the share of the regional and cohesion policy in the EU budget increases, the more the old Member States perceive the CAP as a policy which softens the redistributive effects of other policies by positively affecting their balance.

The considerations concerning the forming of changing Member States coalitions in the EU agricultural policy will concentrate on the answers to the following research questions:

- Which issues related to the CAP reform receive the most attention in the national debate within Member States?

${ }^{7}$ The document entitled "Non-paper on the V4 priorities for the post-2020 Multiannual Financial Framework" developed by the Visegrad Group countries led by Hungary related to the issue of alignment of the direct payments and guaranteeing a level playing field for all EU farmers. 
- What are the topics in the debate on the CAP's future on which coalitions among Member States are built in the EU Council, which issues particularly unite or divide the participants?

- Which of the EU Member States want to abolish the CAP completely or support the CAP liberalisation resulting in its greater marketisation and renationalisation?

- Which states want a significant reduction in CAP expenditure (if so, where would they allocate the saved funds) and which are in favour of maintaining the same level of support for the agricultural sector from the EU budget?

- Which Member States accept the idea of co-financing direct payments from national budgets (and to what extent)? Which Member States are in favour of financing risk management instruments for agriculture at EU level?

- Which states are in favour of strengthening the second pillar of the CAP and thus of a larger budget for rural development?

- Does the line of disagreement over the future financing of the CAP run between the old and new Member States? Are the new Member States consolidated around the proposal for the fastest possible alignment of direct payments in the EU?

- Do the V4 Group members cooperate on the CAP reform or Multiannual Financial Framework discussions?

- Which states support linking the CAP objectives closely with climate policy priorities, e.g. by making the granting of direct payments more conditional on meeting environmental targets (the so-called greening of direct payments)?

\section{Paradigm selection and research techniques and tools}

The assessment of the coalition capacity of individual Member States and the analysis of their voting power in the European arena on issues related to the further reform of the CAP shows that using the liberal inter-governmental approach in the is justified. According to Andrew Moravcsik, the Lead States successfully pursue their national interests considerations by convincing other actors in the negotiating process that the benefits are shared (Moravcsik, 1993). According to the paradigm of inter-governmentalism, the final result of integration is a consequence of the convergence of the strongest countries' interests and gaining support for the proposed solutions through compromises. Observing the decisions on the future of the CAP made in the EU Council, one should remember that they are the result of a competition between particular interests. The Council is an institution where political horse-trading is held, that is an exchange of benefits between individual states, in the form of e.g. adopting package solutions or agreeing on mutual support in later regulatory proposals (Grosse, 2013, p. 138). The attitude towards the future of the EU agricultural policy of the individual participants in the debate would, therefore, depend on their national interests, the aims of which are maintaining prosperity, improving and strengthening the political and economic position of a given country in the EU and gaining more influence.

A helpful paradigm that may also be used to study how Member States coalitions are formed is the multilevel governance theory, which assumes overlapping competencies and interactions among multiple political actors at various levels as well as the 
interdependence between governmental and non-governmental actors (Ruszkowski, 2013, pp. 19-71). It must be emphasised that a major influence on the shape of a state's position on the future of the CAP is very often exerted by the farm lobby (agricultural chambers, food producers' organisations, cooperatives, agricultural trade unions, agrarian parties) (Greta, Tomczak-Woźniak, 2013, pp. 83-90). A major role is also played by those local authorities and regions that are direct beneficiaries of rural development support (structural policy).

The agricultural sector of individual Member States may be characterised with the use of economic indicators and statistical data describing: the volume and structure of agricultural production, productivity, income from a family farm per 1 ha of UAA in EUR/ha, employment in the agri-food industry, as well as problems and challenges characteristic for the structure of rural areas. ${ }^{8} \mathrm{~A}$ reliable source is provided by FADN, the Farm Accountancy Data Network, which publishes regular extensive reports for the European Commission.

The positions on the EC report and the legislative proposals on the CAP are based by the Member States' ministries of foreign affairs and/or ministries of economy, ministries of agriculture, or special administrative units, such as European secretariats, with the prime ministers' approval, on the Member States' existing models for EU policy coordination. Depending on the administrative and territorial structure, the central institutions may be accompanied by bodies at the federal level (as well as Land authorities in Germany). Committees for the European Union in national parliaments will also debate the future of the CAP and evaluate the proposed changes in agriculture. Meetings of the Member States' ministers of agriculture, signing declarations made in the context of regional organisations and conclusions adopted during the EU Council presidency provide Member States with an opportunity to express their positions. It is important to note the Presidency Report for the period between January 2018 and the end of June 2019 by the Member States making up the Trio: Bulgaria - Austria - Romania. Views on the CAP are revealed during negotiations on the Multiannual Financial Framework when the states develop their strategies, set priorities by graduating the importance of EU policies according to national interest and enter into coalitions with other states.

Member States are involved in the debate on the future of the CAP to varying degrees. Drawing upon the experience of the earlier reforms, it may be assumed that the active states will include Germany, Italy, Spain and some of the new EU members, such as Poland, as well as Bulgaria and Romania, which is even more important as those two latter states held the EU Council Presidency in the key period for the debates on the shape of the CAP post-2020.

Conducting qualitative research in the individual Member States in the form of individual in-depth interviews with officers of the ministries of agriculture and experts from research institutes, providing the analytic background for the governments, as well as with representatives of institutions and organisations associating bodies interested in the shape of agricultural policy must therefore be considered as valid (Wiśniewska, 2013, p. 62). Referring to the positions of Member States in the form of

${ }^{8}$ Rural structures comprise: the number and age of farmers, the number and size of holding, farm equipment, farmers' education, producer groups, processing and merchandising agricultural commodities (Jesień, 2007, p. 82). 
governmental documents on the subsequent reforms and shape of the CAP as well as to the directives and regulations of the EU institutions provides grounds for the application of the formal-legal analysis method. A helpful method for presenting similarities and differences between national priorities of individual countries in their approach to the CAP is the comparative method, which also allows evaluating the probability of forming a coalition and establishing cooperation between countries on a given issue. The application of the decision-making method allows to analyse phenomena and processes concerning both the CAP reform and the transformation of towns and villages in Member States through the prism of political decisions made at the level of Member States' governments and EU institutions as well as the implementation and consequences of the solutions adopted.

\section{Conclusions}

The 2017 and 2018 EC's proposals (including three regulations from the CAP reform package concerning the Multiannual Financial Framework for the years 20212027) are the beginning of the formal negotiation process among the Council, the European Parliament and the European Commission. The definitive determinations concerning both the shape of the CAP and the maximum budget allocated to agricultural policy and its distribution are the result of the decisions which will be made in 2019. Those Member States' governments that argue in favour of alignment of direct payments and call for the highest possible level of rural development support must choose their arguments carefully and seek coalition partners who share their point of view of the proposed CAP reform. The reality of EU decision-making clearly shows that success in negotiations may only be achieved in cooperation with the other Member States. Results of the 2017 citizens' consultations prove that the public opinion and experts and politicians hold diverse visions and views of the objectives and tasks of agricultural policy and the farming sector. The CAP has been subject to ongoing reform since the 1960 s, so presumably its post-2020 shape will also change with time and, when debating the role, financing and future of the CAP, Member States will form coalitions and look to make negotiation alliances.

\section{Bibliografia}

Babiak J. (2010), Zmiany w strukturze rolnictwa krajów Unii Europejskiej, „,Rocznik Integracji Europejskiej", $\mathrm{nr} 4$.

Baer-Nawrocka N., Markiewicz A. (2010), Zróżnicowanie przestrzenne potencjału produkcyjnego rolnictwa w krajach Unii Europejskiej, „Roczniki Nauk Rolniczych”, nr 4.

Bielka I. (2013), Kontrowersje i spory wokót perspektywy budżetowej Unii Europejskiej na lata 2014-2020, „Przegląd Prawniczy Ekonomiczny i Społeczny”, nr 3.

Biernat-Jarka A. (2016), Ptatności bezpośrednie w Polsce i UE, „Infos Bas”, nr 19 (223).

Bryła P. (2008), Stosunek Francji do zmian Wspólnej Polityki Rolnej, „Studia Europejskie”, nr 3.

Czyżewski A., Stępień S. (2011), Wspólna polityka rolna po 2013 r. a interesy polskiego rolnictwa, „Ekonomista”, nr 1. 
Czyżewski A., Stępień S. (2012), Punkt widzenia Polski i innych Państw Członkowskich Unii Europejskiej na WPR 2014-2020, „Journal of Agribusiness and Rural Development”, 3 (25).

Czyżewski A., Stępień S. (2012), Wspólna polityka rolna - doświadczenia i przyszłość, „Przegląd Prawa Rolnego", nr 2 (11).

Drygas M., Nurzyńska I. (2018), Uwarunkowania dyskusji nad kształtem Wspólnej Polityki Rolnej po 2020 roku, „Zeszyty Naukowe SGGW w Warszawie Problemy Rolnictwa Światowego”, tom 18 , z. 2.

Dybowski G. (red.) (2008), Margines swobody dla strategii narodowych w ramach Wspólnej Polityki Rolnej. Doświadczenia wybranych krajów Unii Europejskiej, Instytut Ekonomiki Rolnictwa i Gospodarki Żywnościowej Państwowego Instytutu Badawczego, Warszawa.

Greta M., Tomczak-Woźniak E. (2013), Europejskie organizacje rolnicze i ich oddziaływanie na spoleczno-ekonomiczne przemiany w rolnictwie, ,Journal of Agribusiness and Rural Development" 2(28).

Grochowska R., Wigier M. (red.) (2013), Wspólna Polityka Rolna po 2013 roku - zagadnienia wybrane, Instytut Ekonomiki Rolnictwa i Gospodarki Żywnościowej Państwowego Instytutu Badawczego, Warszawa.

Grochowska R., Kiryluk-Dryjsk E. (2016), Przewidywanie potencjalnych rozwiązan dla wieloletnich ram finansowych UE po 2020 roku przy wykorzystaniu teorii gier, „Zeszyty Naukowe SGGW w Warszawie. Problemy Rolnictwa Światowego"t. 16, z. 2.

Grochowska R., Kosior K. (2016), Negocjacje budżetowe Unii Europejskiej w cieniu zasady juste retor, „Zagadnienia Ekonomiki Rolnej”, nr 4(349).

Grosse T. G. (2013), O polityczności dwupoziomowego systemu politycznego w Europie, w: Multi-level Governance w Unii Europejskiej, red. J. Ruszkowski, L. Wojnicz, Instytut Politologii i Europeistyki Uniwersytetu Szczecińskiego Instytut Europeistyki Uniwersytetu Warszawskiego, Szczecin-Warszawa.

Hadyńska A., Hadyński J. (2008), Stanowisko Niemiec wobec Health Check WPR 2008, w: Reforma Wspólnej Polityki Rolnej z 2008 r. z punktu widzenia interesów wybranych państw członkowskich, Urząd Komitetu Integracji Europejskiej, Warszawa.

Jesień L. (2007), Wstęp do wybranych polityk Unii Europejskiej, Wyższa Szkoła Europejska im. ks. Józefa Tischnera, Kraków.

Kleinowski M. (2009), Wpływ traktatu lizbońskiego na pozycje państw członkowskich, w: Polityczne dylematy Europy, red. W. Gizicki, Wydawnictwo Adam Marszałek, Torun.

Kleinowski M. (2014), Siła państw w Unii Europejskiej. Formalnoprawne wyznaczniki sity państw w Radzie UE i Radzie Europejskiej, Wydawnictwo Adam Marszałek, Toruń.

Komisja Europejska Wniosek rozporządzenie Parlamentu Europejskiego i Rady w sprawie finansowania Wspólnej Polityki Rolnej, zarzadzania nia i monitorowania jej oraz uchylajace rozporzadzenie (UE) nr 1306/2013 Bruksela (2018), dnia 1.06.2018 COM(2018) 393 final https:// ec.europa.eu/transparency/regdoc/rep/1/2018/PL/COM-2018-393-F1-PL-MAIN-PART-1. PDF, 4.12.2018.

Komunikat Komisji do Parlamentu Europejskiego, Rady Europejskiej, Rady, Europejskiego Komitetu Ekonomiczno-Społecznego i Komitetu Regionów, Nowoczesny budżet dla Unii, która chroni, wspiera i broni Wieloletnie ramy finansowe na lata 2021-2027, Bruksela, dnia 2.05.2018 r. COM(2018) 321, http://ec.europa.eu/transparency/regdoc/rep/1/2018/PL/COM2018-321-F1-PL-MAIN-PART-1.PDF, 4.12.2018.

Komunikat Komisji do Parlamentu Europejskiego, Rady, Europejskiego Komitetu Ekonomiczno-Społecznego i Komitetu Regionów Przyszłość rolnictwa i produkcji żywności, Bruksela, dnia 29.11.2017 r. COM(2017)713), https:/www.gov.pl/documents/912055/913531/tekst+dok_ en.pdf/a92d8118-e662-2038-76b0-f948e4c16b8e, 4.12.2018. 
Kosior K. (2011), Koncepcje reform Wspólnej Polityki Rolnej Unii Europejskiej po 2013 roku, „Gospodarka Narodowa”, nr 5-6.

Kosior K. (2014), Zmiany priorytetów i paradygmatów zachodzace w ramach strategii rozwojowych sektora rolnego w UE na tle globalnym, w: Kierunki rozwoju rolnictwa i polityk rolnych - wyzwania przyszłości (synteza), red. R. Grochowska, Instytut Ekonomiki Rolnictwa i Gospodarki Żywnościowej Państwowego Instytutu Badawczego, Warszawa.

Kowalski A., Wigier M., Bułkowska M. (red.) (2013), Nowe rozwiazania WPR 2013+ wobec wyzwań rolnictwa krajów członkowskich Unii Europejskiej, Instytut Ekonomiki Rolnictwa i Gospodarki Żywnościowej Państwowego Instytutu Badawczego, Warszawa.

Ławniczak K. (2017), Społeczne zakorzenienie aktorów procesu podejmowania decyzji w Radzie Unii Europejskiej, Wydawnictwo Naukowe Scholar, Warszawa.

Ławniczak K. (2014), Rada Unii Europejskiej. Organizacja i sposób działania, Wydział Dziennikarstwa i Nauk Politycznych, Warszawa.

Łoś-Nowak T. (1997), Interesy narodowe i międzynarodowe, w: Współczesne stosunki międzynarodowe, red. T. Łoś-Nowak, Wydawnictwo Uniwersytetu Wrocławskiego, Wrocław.

Majewski A., Malak-Rawlikowska A. (2018), Scenariusze Wspólnej polityki rolnej po 2020 roku, „Problems of Agricultural Economics” Zagadnienia Ekonomiki Rolnej, 1(354).

Miecznikowska J. (2016), Wspólna Polityka Rolna w czasie kryzysu, w: Polityki Europejskie w dobie kryzysu, red. T. G. Grosse, Wydawnictwo Naukowe Scholar, Warszawa.

Modernising and Simplifying the Common Agricultural Policy, https://ec.europa.eu/agriculture/ sites/agriculture/files/consultations/cap-modernising/highlights-public-consul_en.pdf, 4.12.2018.

Modernising and Simplifying the Common Agricultural Policy, Summary of the results of the public consultation, European Commission - DG AGRI Brussels 7 July 2017, https://ec.europa. eu/agriculture/sites/agriculture/files/consultations/cap-modernising/summary-public-consul. pdf, 30.11.2019.

Moravcsik A. (1993), Preferences and Power in the European Community. A liberal intergovernmentalist Approach, ,Journal of the Common Market Studies”, vol. 31.

Nawrot B. (2008), Analiza proponowanej reformy Wspólnej Polityki Rolnej (tzw. Health Check) z punktu widzenia interesów Wielkiej Brytanii, w: Reforma Wspólnej Polityki Rolnej z 2008 r. z punktu widzenia interesów wybranych państw członkowskich, Urząd Komitetu Integracji Europejskiej, Warszawa.

Non-paper on the V4 priorities for the post-2020 Multiannual Financial Framework, http://v4.gov. hu/download/b/c3/12000/V4\%20MFF\%20non-paper\%205\%20January\%202018.pdf, 4.12.2018.

Poczta W. (2011), Wspólna polityka rolna Unii Europejskiej po 2013 roku-wizje zmian, w: Projekty inwestycyjne w agrobiznesie a zasady Wspólnej Polityki Rolnej po 2013 r., red. A. Czyżewski, W. Poczta, Wydawnictwo Uniwersytetu Przyrodniczego w Poznaniu, Poznań.

Poczta W. (red.) (2013), Gospodarstwa rolne w Polsce na tle gospodarstw Unii Europejskiej-wptyw $W P R$, Instytut Ekonomiki Rolnictwa i Gospodarki Żywnościowej Państwowego Instytutu Badawczego, Warszawa.

Popławski K. (2011), WPR 2008 oraz Niemcy wobec Wieloletnich Ram Finansowych Unii Europejskiej na lata 2014-2020 - uwarunkowania i interesy, Raport Ośrodka Studiów Wschodnich im. M. Karpia, Warszawa.

Prus P., Mickiewicz B. (2014), Analiza porównawcza instrumentów wsparcia WPR w ramach wieloletniej perspektywy finansowej 2014-2020 w stosunku do WPR 2007-2013, „Journal of Agribusiness and Rural Development", nr 4(34). 
Purgał P. (2011), Determinanty reformy Wspólnej Polityki Rolnej w perspektywie 2020 roku, w: Projekty inwestycyjne w agrobiznesie a zasady Wspólnej Polityki Rolnej po 2013 r., red. A. Czyżewski, W. Poczta, Wydawnictwo Uniwersytetu Ekonomicznego w Poznaniu, Poznań.

Puślecki Z. W., Kmieciak R., Walkowski M. (2010), Wspólna Polityka Rolna w warunkach wzrostu konkurencyjności Unii Europejskiej, Dom Wydawniczy Elipsa, Warszawa.

Rembisz W., Kulak R. (2010), Wizje przyszłości Wspólnej Polityki Rolnej-głosy uczestników rynku rolno-spożywczego i gremiów decyzyjnych w UE, „Biuletyn informacyjny Agencji Rynku Rolnego", nr 4 (226).

Ruszkowski J. (2013), Struktura wielopoziomowego zarzadzania w Unii Europejskiej, w: Multi-level Governance w Unii Europejskiej, red. J. Ruszkowski, L. Wojnicz, Instytut Politologii i Europeistyki Uniwersytetu Szczecińskiego, Instytut Europeistyki Uniwersytetu Warszawskiego, Szczecin-Warszawa.

Strategic approach to EU agricultural research and innovation, 2016, European Commission, final paper, RES (16) 6957: 1.

Szuba E., Mrówczyńska-Kamińska A. (2014), Znaczenie sektora rolno-żywnościowego w gospodarkach państw Europy Środkowo-Wschodniej, „Journal of Agribusiness and Rural Development", $\mathrm{nr} 32$.

Świstak M. (2015), Wspólna Polityka Rolna, w: M. Świstak, J. W. Tkaczyński, Wybrane polityki publiczne Unii Europejskiej. Stan i perspektywy, Kraków.

Tomaszyk M. (2013), Wptyw kryzysu ekonomicznego na procedowanie i ksztalt Ram Finansowych na lata 2014-2020, w: Między polityka a rynkiem. Kryzys Unii Europejskiej w analizie ekonomistów i politologów, red. T. G. Grosse, Dom Wydawniczy Elipsa, Warszawa.

Walkowski M. (2007), Regionalne i globalne uwarunkowania reform Wspólnej Polityki Rolnej Unii Europejskiej, Wydawnictwo Naukowe INPiD Uniwersytetu im. Adama Mickiewicza, Poznań.

Wilkin J. (2008), Ekonomia polityczna systemu wsparcia bezpośredniego w ramach Wspólnej Polityki Rolnej, ze szczególnym uwzględnieniem sytuacji w nowych państwach członkowskich $U E$, Instytut Ekonomiki Rolnictwa i Gospodarki Żywnościowej Państwowego Instytutu Badawczego, Warszawa.

Wilkin J. (2009), Ekonomia polityczna reform Wspólnej Polityki Rolnej, „Gospodarka Narodowa”, nr $1-2$.

Wiśniewska J. (2013), Wywiad jako technika gromadzenia danych w badaniach jakościowych, w: Metody jakościowe i ilościowe w badaniach organizacji i działania Unii Europejskiej, red. K. Ławniczak, Wydział Dziennikarstwa i Nauk Politycznych, Warszawa.

Zawojska A. (2006), Paradygmaty dla współczesnego rolnictwa - protekcjonizm kontra liberalizm, „Roczniki Nauk Rolniczych”, t. 92, z. 2.

Wniosek dotyczący rozporządzenia Parlamentu Europejskiego i Rady ustanawiajacego przepisy dotyczace wsparcia na podstawie planów strategicznych sporządzanych przez państwa członkowskie w ramach wspólnej polityki rolnej (planów strategicznych WPR) i finansowanych z Europejskiego Funduszu Rolniczego Gwarancji (EFRG) i z Europejskiego Funduszu Rolnego na rzecz Rozwoju Obszarów Wiejskich (EFRROW) oraz uchylającego rozporzadzenie Parlamentu Europejskiego i Rady (UE) nr 1305/2013 i rozporzadzenie Parlamentu Europejskiego i Rady (UE) nr 1307/2013.

Wniosek dotyczący rozporządzenia Parlamentu Europejskiego i Rady w sprawie finansowania wspólnej polityki rolnej, zarządzania nia i monitorowania jej oraz uchylającego rozporzadzenie (UE) nr 1306/2013.

Wniosek dotyczący rozporządzenia Parlamentu Europejskiego i Rady zmieniajacego rozporzadzenia (UE) $n r$ 1308/2013 ustanawiajace wspólnq organizację rynków produktów rolnych, (UE) nr 1151/2012 w sprawie systemów jakości produktów rolnych i środków spożywczych, (UE) 
nr 251/2014 w sprawie definicji, opisu, prezentacji, etykietowania i ochrony oznaczeń geograficznych aromatyzowanych produktów sektora wina, (UE) $n r$ 228/2013 ustanawiajace szczególne środki $w$ dziedzinie rolnictwa na rzecz regionów najbardziej oddalonych $w$ Unii Europejskiej $i$ (UE) nr 229/2013 ustanawiające szczególne środki dotyczące rolnictwa dla mniejszych wysp Morza Egejskiego.

\section{Summary}

This article is a conceptualization study aiming to provide the groundwork for research into the formation of changing coalitions among European Union Member States. Firstly, it assesses the current state of research, follows with a selection of research problems and provides validation for the research considerations raised. It poses research hypotheses and questions that verify the hypotheses. The latter part of the article attempts to identify the paradigms, techniques and tools able to diagnose the research problems posed.

Key words: European Union, Common Agricultural Policy, coalitions, EU member states, Multiannual Financial Framework

\section{Ksztaltowanie się zmiennych koalicji w polityce rolnej Unii Europejskiej - założenia konceptualizacyjne badań politologicznych}

\section{Streszczenie}

Artykuł jest opracowaniem konceptualizacyjnym stanowiącym przygotowanie do badań nad kształtowaniem się zmiennych koalicji między państwami członkowskimi w polityce rolnej Unii Europejskiej. W pierwszej kolejności dokonana została ocena stanu badań, następnie przeselekcjonowano problemy uzasadniając zasadność prowadzonych rozważań. Zaproponowano hipotezy badawcze wraz z pytaniami prowadzącymi do weryfikacji hipotez. W dalszej części artykułu podjęto próbę wskazania paradygmatów oraz technik i narzędzi pomocnych w zdiagnozowaniu zaproponowanych problemów badawczych.

Słowa kluczowe: Unia Europejska, Wspólna Polityka Rolna, koalicje, państwa członkowskie UE, Wieloletnie Ramy Finansowe 
